\title{
Effects of COVID-19 on Global Financial Markets: Evidence from Qualitative Research for Developed and Developing Economies
}

\author{
Linhai Zhao ${ }^{1}$ Ehsan Rasoulinezhad ${ }^{2} \cdot$ Tapan Sarker $^{3}$. \\ Farhad Taghizadeh-Hesary ${ }^{4}($ )
}

Accepted: 25 October 2021 / Published online: 21 January 2022

(c) European Association of Development Research and Training Institutes (EADI) 2021

\begin{abstract}
The research aims to prioritize the pandemic's impact on the financial markets of developed and developing economies using a multi-criteria decision-making approach. The results revealed that COVID-19's pandemic effects on financial markets differ between developed and developing nations. COVID-19 pandemic affects developed countries' financial markets more through supply reduction, demand reduction, and economic instability. Regarding developing nations, confidence and expectations, changes in consumption patterns, and the bandwagon effect are the three most significant impacts of COVID-19 pandemic on financial markets. The best decisions to lower the effect of COVID-19 pandemic on developed nations' financial markets are the declaration of the stimulus package and support of smalland-medium-sized enterprises. Contrastingly, in developing countries, support for vulnerable households and declaration of the stimulus package are the best decisions to combat COVID-19's negative impact on their financial markets. As practical policy implications for lowering COVID-19's negative impact on financial markets, the promotion of new financing instruments, reconstruction of the relationship between public and private sectors, and support of vulnerable households and enterprises are highly recommended.
\end{abstract}

Keywords External shock $\cdot$ COVID-19 $\cdot$ Global financial markets $\cdot$ Sustainable development goals $\cdot$ Analytic hierarchy process

Farhad Taghizadeh-Hesary

farhad@ @sc.u-tokai.ac.jp

1 School of Economics and Finance, Huaqiao University, Quanzhou, China

2 Faculty of World Studies, University of Tehran, Tehran, Iran

3 Griffith Business School, Griffith University, Brisbane, Australia

4 Social Science Research Institute, Tokai University, Hiratsuka-shi, Kanagawa 259-1292, Japan 


\section{Résumé}

La recherche vise à hiérarchiser l'impact de la pandémie sur les marchés financiers des économies développées et en développement en utilisant une approche décisionnelle à plusieurs critères. Les résultats ont révélé que les effets du COVID-19 sur les marchés financiers diffèrent entre les nations développées et en développement. Le COVID-19 affecte davantage les marchés financiers des pays développés par la réduction de l'offre, la réduction de la demande et l'instabilité économique. En ce qui concerne les pays en développement, la confiance et les attentes, les changements dans les habitudes de consommation et l'effet boule de neige sont les trois impacts les plus significatifs causé par le COVID-19 sur les marchés financiers. Les meilleures décisions pour réduire l'effet du COVID-19 sur les marchés financiers des pays développés ont été la déclaration de plans de relance et le soutien aux petites et moyennes entreprises. En revanche, dans les pays en développement, le soutien aux ménages vulnérables et la déclaration de plans de relance apparaissent comme les meilleures décisions pour combattre l'impact négatif du COVID-19 sur leurs marchés financiers. En ce qui concerne les implications politiques pratiques pour réduire l'impact négatif du COVID-19 sur les marchés financiers, la promotion de nouveaux instruments de financement, la reconstruction de la relation entre les secteurs public et privé, et le soutien des ménages et des entreprises les plus vulnérables sont fortement recommandés.

JEL Classification N0 $\cdot \mathrm{N} 10 \cdot \mathrm{O} 10$

\section{Introduction}

The novel coronavirus disease (COVID-19) is an infectious disease that spreads rapidly to almost all countries worldwide and caused a global pandemic. The total cases and mortalities due to COVID-19 pandemic have increased sharply in the last months of 2020 and in 2021. This rapid spread of cases and deaths due to the COVID-19 pandemic had a significant negative impact on the global economy and on the financial markets.

This global crisis that has been described as "humanity's worst crisis since World War II" by the UN Secretary-General Antonio Guterres (France24 2020), strongly impacted different aspects of the global economy (Donthu and Gustafsson 2020; Louhichi et al. 2021; Mulugeta et al. 2021; Padhan and Prabheesh 2021; Wunder et al. 2021; Vieira et al. 2021), by nearly 2.7 trillion US dollars as estimated by Bloomberg (Bloomberg 2020). Based on the OECD Interim Economic Outlook (March 2020), the pandemic is a crucial threat to the economic growth of all countries in 2020. Table 1 reports real GDP growth for some countries from 2019 to 2021:

The pandemic's main challenge for the global economy is its negative consequences on efforts to achieve the 2030 agenda for sustainable development (Elavarasan et al. 2021; Fagbemi 2021). The pandemic has created an unprecedented situation in which the potential threats for social health, education, economy, and green 
Table 1 Real GDP growth of countries, 2019-2021, \%

\begin{tabular}{llll}
\hline Countries & 2019 & 2020 & 2021 \\
\hline G20 & 3.1 & 2.7 & 3.5 \\
Canada & 1.6 & 1.3 & 1.9 \\
Euro area & 1.2 & 0.8 & 1.2 \\
Germany & 0.6 & 0.3 & 0.9 \\
Japan & 0.7 & 0.2 & 0.7 \\
United States & 2.3 & 1.9 & 2.1 \\
Brazil & 1.1 & 1.7 & 1.8 \\
China & 6.1 & 4.9 & 6.4 \\
India & 4.9 & 5.1 & 5.6 \\
Russia & 2 & 1.2 & 1.3 \\
World & 2.9 & 2.4 & 3.3 \\
\hline
\end{tabular}

Source Authors' compilation from OECD Economic Outlook report (https://www.oecd.org/berlin/publikationen/Interim-Economic-Asses sment-2-March-2020.pdf)

projects have increased sharply. Governments have faced many new fiscal challenges that can be considered a threat to achieving sustainable development goals (SDGs). Fenner and Cernev (2021), Wang and Huang (2021), and Taghizadeh-Hesary et al. (2021) argue that the negative consequences of pandemics have diverted funding to SDGs. Pan and Zhang (2020) state that one of the major impacts of the pandemic on the global economy is its role in the de-globalization of development and lowering the financing power of governments to reach a higher level of development that is against the targets of SDGs. Therefore, it can be addressed that the pandemic can negatively impact the achievement of the 17 defined SDGs (s) by the United Nations (e.g., see SDG1 (no poverty), SDG2 (zero hunger), SDG3 (good health and wellbeing), SDG4 (quality education), SDG8 (decent work and economic growth), SDG 10 (reduced inequalities), SDG 13 (climate action).

One of the most important markets in the global economy is the financial market, which forms financial flows worldwide. Global financial markets are vulnerable to various crises. Pitterle et al. (2015) argue that crises, particularly external ones, may cause economic slowdown, leading to rapid and continued commodities and financial market disequilibrium. COVID-19 is considered an external shock and crisis (UNCTAD 2020; Vittuari et al. 2021) for all countries globally, depicting that the financial market is experiencing vulnerability to the current pandemic. For instance, according to the volatilities of the important stock index of the S\&P 500 (stock performance of 500 large economic firms in stock exchanges in the U.S.) shown in Fig. 1, it can be expressed that stock prices have faced great stress and reduction in the last months due to the pandemic and the uncertainty of its impacts on the global economy.

The trend of this index shows that since late February 2020, the stock price has experienced adverse change. However, due to the news about the Federal Reserve intervention and a financial support package (Martin 2020), the price has recovered since late March 2020. 


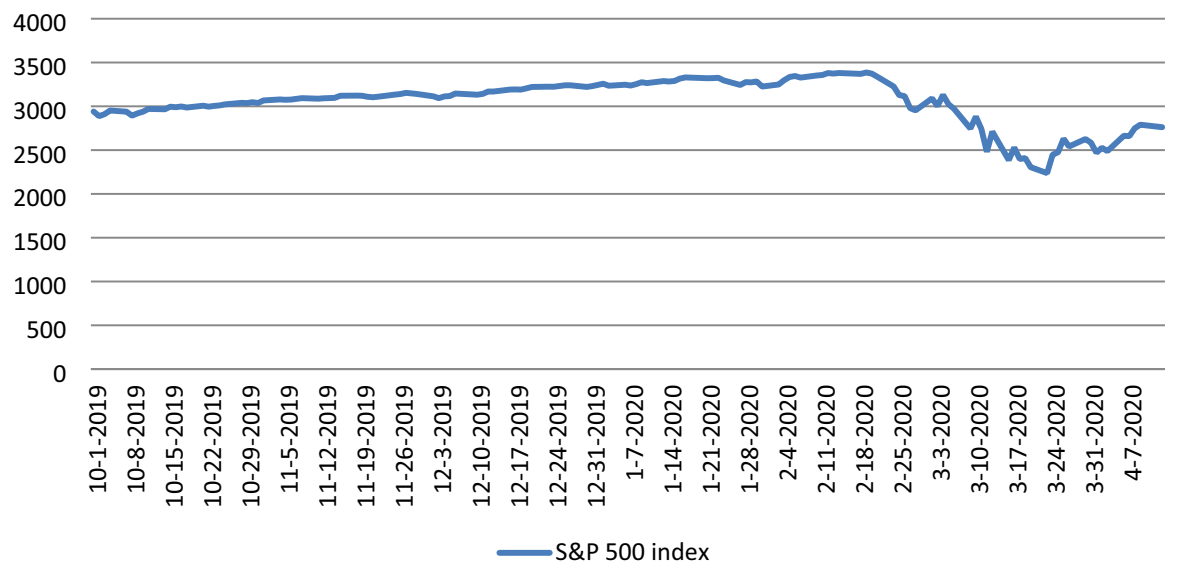

Source: Authors' compilation based on https://us.spindices.com/indices/equity/sp-500

Fig. 1 Trend of S\&P 500 index (10.01.2019-14.04.2020). Source Authors' compilation based on https:// us.spindices.com/indices/equity/sp-500

Following the Center for Strategic and International Studies (CSIS) report in 2020, global commodities and financial markets are negatively affected by both demand and supply shocks resulting from COVID-19. Albulescu (2021) and Yousfi et al. (2021) show that the pandemic increases the volatility of financial markets in the US. The significant impact of the pandemic on financial markets has been expressed and proven by other scholars such as So et al. (2021) for the case of Hong Kong, Lyocsa et al. (2020) for the case of 10 famous indices, Ozkan (2021) for six developed countries, and Zaremba et al. (2021) for 49 countries.

Shiller (2020) believes that COVID-19 has brought pandemics of health and anxiety over the economic consequences of the pandemic. The second pandemic (the gray future of the global economy) as a negative signal may have hit financial markets in all countries. Therefore, studying and gathering financial experts' opinions about the impacts of this decrease on the financial markets of developed and developing nations may bring fruitful results and concluding remarks for policymakers and scholars.

Despite some earlier studies on the effects of external shocks on financial markets, such as Bancit et al. (2016), Jin and An (2016), Castagneto-Gissey and Nivorozhkin (2016), Ankudinov et al. (2017), Atkins et al. (2018), Liu et al. (2019), and Samadi et al. (2021), this is the first study to consider and prioritize the impacts of COVID-19 on financial markets in developed and developing nations. To this end, we analyze the experts' opinions through an MCDM (Multi-Criteria Decision Making) approach, namely Analytic Hierarchy Process (AHP), and based on the empirical part, we recommend some policy implications to enable financial markets to recover, which means opportunities for countries to improve the progress of SDGs.

This study contributes to the existing literature in different ways. First, the study of the impact of the pandemic on financial markets has been performed through a decision-making approach, namely AHP. This contribution provides the qualitative 
findings which can be addressed as the complementary materials for the quantitative results. Second, the analysis of impacts was carried out separately for developed and developing nations. This would be a fruitful research strategy due to the dissimilarities of developed and developing nations in the fields of capital power, market infrastructures and financial absorption. Third, the issue of how COVID-19 can affect financial markets is studied based on experts' opinions and the concept of pairwise comparisons. This may solve the problem of inconsistency and validation of qualitative research methods.

The major findings of this research reveal that the effects of COVID-19 on financial markets differ between developed and developing nations. Hence, there is no similar pattern of COVID-19's impact on financial markets among all countries' levels. The economic criterion is the most essential transmission channel of COVID-19 to the financial markets of developed nations. In contrast, the social criterion has a more prominent role than the economic one as a transmission channel in the financial markets of developing nations. COVID-19 affects developed countries' financial markets more through supply reduction, demand reduction, and economic instability. Regarding developing nations, the experts believed that confidence and expectations, changes in consumption patterns, and the bandwagon effect are the three most significant impacts of COVID-19 on financial markets.

The remainder of this paper is organized as follows: 'Literature Review' discusses the existing literature. The next section explains the methodology used in this study. 'Empirical Results' presents the empirical findings, and the last section concludes the paper with some policy implications.

\section{Literature Review}

The related literature can be divided into two strands: (i) a group of studies focusing on the effects of external shocks on financial markets and (ii) existing literature on the effects of COVID-19 on economic and financial markets.

The first strand of the literature concentrates on the responses of financial markets to shocks and crises. Adedapo Soyemi et al. (2017) investigated the oil price shock in the financial markets of Nigeria from 2007 to 2014. They found that this unexpected external shock can affect the stock market directly and indirectly from the commodity market. The effect of such an unexpected shock has been proven by several scholars. For instance, Bastianin et al. (2016) discuss that unexpected shocks with the source of demand shocks can significantly impact stock market volatility in the G7 countries. The nature of shocks (demand or supply-side) is a major factor that represents the level of external shock in the financial market. Le and Chang (2015) investigated the nature of shocks and their effects on stock market performance using generalized impulse response functions for monthly data from 1997 to 2013. The major results revealed that the nature of the shock is important because a financial market reacts differently to shocks in demand and supply. Another external shock is political risk, such as war risk, which can affect global financial markets. Rigobon and Sack (2005) investigated the relationship between the US and Iraq war and some US financial variables. The major findings showed that with an increase 
in war risk, the dollar and oil prices might decrease and increase, respectively. In addition, Hudson and Urquhart (2015) studied the effect of World War II as an exogenous shock on the British stock market and proved the negative effect of this kind of shock on the stock market. This negative effect of war risk has been found by other scholars, such as Schneider and Troeger (2006), Ferguson (2008), and Balcilar et al. (2016). A natural disaster is another exogenous shock that may lead to deep fluctuations in financial markets. Romero Cortes and Strahan (2017) studied how banks adapt their credit supply decisions in response to exogenous shocks to credit demand. The major findings reveal that even small banks effectively smooth shocks, even without access to national or global capital markets. Lewis and Liu (2017) investigated the relationship between disaster risk and asset returns. They found a significant negative impact of disaster risk on equity markets. Rehse et al. (2019) attempted to determine the effects of Hurricane Sandy as an exogenous shock on market liquidity. The findings confirmed the theory of the detrimental effects of natural disasters on market functioning. One consequence of exogenous shocks such as natural disasters, war risk, or commodity price shocks is creating uncertainty in economic and financial markets. Li et al. (2016) explained that exogenous shocks could affect economic and financial markets by creating uncertainty. Yildirim-Karaman (2018) investigated uncertainty in financial markets and business cycles. They found that uncertainty refers to the unclear future performance of the stock, which negatively affects investors' activities in the stock market. This negative impact of uncertainty on the performance of financial markets has been proven by many scholars, such as Ackert (1994), Dzielinski (2012), Vorbrink (2014), Segal et al. (2015), Chulia et al. (2017), and Wang and Boatwright (2019). However, Wu et al. (2021) argued that cooperation between the government, the market, and various social organizations can create an economic structure that may be affected less by the pandemic. In addition, some studies (e.g., Li et al. 2021; Taghizadeh-Hesary et al. 2021; and Yoshino et al. 2021) have proposed financial instruments and policies to lower the negative impacts of COVID-19 on financial markets.

The second strand of the existing literature contains studies on the effects of COVID-19 on economic and financial markets. Pak et al. (2021) mentioned that the vast number of governments in the world underestimated the negative consequences of the rapid pandemic outbreak, leading to inefficient reactions to the negative consequences of COVID-19. Atkeson (2020) investigated the future economic impact of COVID-19 in the US. He found that if the number of infections increases, the US will experience severe staffing shortages for key financial and economic infrastructure. McKibbin and Fernando (2020) defined seven scenarios for the global macroeconomic impact of this pandemic. The results showed that the decrease could affect the global economy in the short run, and in response, all economies will increase investment in health systems to combat the likely long-run effects of COVID-19. Baker et al. (2020) focused on the impact of COVID-19 on the stock market. The results revealed the unprecedented impact of this decrease on market volatility in the US. Gormsen and Koijen (2020) sought to determine the relationship between coronavirus, stock prices, and growth expectations. They concluded that this decrease has strongly affected all stock prices in global stock markets more than growth expectations in the US. OECD (2020), in the report of the OECD Interim Economic 
Assessment, mentioned that this virus should be considered as a major risk for the world economy due to its large economic disruption, weakening global trade flows, lowering the level of industrial production, and reducing consumption on the demand side of the commodities market. Elliott (2020) argues that the coronavirus crisis, like the Great Depression of 1929, may cause us to abandon oil economic policies and create new economic thinking to save the global economy. Samadi et al. (2021) argued that for an under-crisis country such as Iran, the pandemic brings more confusion and uncertainty in the investment and industrial production sectors. Barrafrem et al. (2020) conducted a survey to determine people's opinions in Sweden and England about the future of their lives. The major results addressed the predicted inappropriate financial situation of countries after the COVID-19 outbreak. So et al. (2021) used network analysis to determine the impact of the pandemic on financial market connectedness. The results show that the pandemic increases systemic risk in financial markets, which has more impressive negative impacts than previous financial crises in the past 15 years. Yoshino et al. (2021) theoretically show that investors' current allocation by considering SDG based on various consulting companies will distort the investment portfolio post-COVID-19. According to their study, the desired portfolio allocation can be achieved by taxing pollution and waste, such as $\mathrm{CO} 2, \mathrm{NOx}$, and plastics, globally, with the same tax rate. Global taxation on pollution will lead to the desired portfolio allocation of assets. In another studies, Ozkan (2021),Vera-Valdes (2021) and Li and Yan (2021) sought to determine how COVID-19 affected the financial markets in six developed nations. They found that the pandemic increased the volume of fluctuations and imbalances in the markets, particularly in the United States and the UK. This finding is similar to that of other studies, such as Uddin et al. (2021) for 34 developed and emerging economies and Aharon and Siev (2021) for 25 international capital markets.

Overall, the existing literature highlights the lack of sufficient academic studies on the effects of COVID-19. In particular, since this issue is fresh, complex, and multi-dimensioned, it is necessary to employ an appropriate technique to address the problem of lack of quantitative data. To this end, this study seeks to contribute to the existing literature by using a multi-criteria decision-making model (MCDM), namely AHP, to identify and prioritize the impacts of COVID-19 on financial markets of developed and developing nations. Therefore, we will try to fill this gap in the literature by using the AHP technique to analyze experts' opinions about the impacts of COVID-19 on global financial markets.

\section{Methodology}

In this study, we seek to determine the priorities of the different impacts of COVID19 on global financial markets. To this end, we carry out a qualitative method called AHP, proposed by Saaty and Vargas (1980), and help analyze different experts' opinions to set priorities and make the most appropriate decision. By decreasing the complex structure of decisions to groups of pairwise comparisons and then synthesizing experts' judgments, this method helps to rank the factors. Furthermore, AHP 
has an index to check the consistency of experts' judgments, lowering the bias in decision-making and increasing the reliability of the final results.

The AHP method is appropriate for this study is because it can help scholars make a new and multidimensional economic issue more understandable and easier to solve. Chai et al. (2013) mentioned that for some new economic challenges, quantitative variables do not exist; therefore, we need to solve or interpret these challenges through appropriate qualitative techniques such as AHP. In addition, the impacts of the pandemic on financial markets can become more obvious through the concept of pairwise comparisons in AHP, which is mathematically more comprehensive and appropriate than comparing several criteria at once. This character of AHP makes the analysis dynamic and more logical. Moreover, the AHP transforms the economic research problem into a structured and transparent framework that is easier to analyze by scholars (Gompf et al. 2021).

To apply AHP, we first need to clarify the main problem (effects of COVID-19 on global financial markets) and design the problem structure by considering all criteria and sub-criteria. Next, different experts (the group of experts included seven assistant professors and four associate professors specialized in financial economics) evaluated the importance of criteria and sub-criteria in the form of pairwise comparisons. In our research, ten experts of the financial economy and global economy carried out the comparisons based on the fundamental scale of Saaty, as presented in Table 2. To select the appropriate experts, firstly a list of experienced experts who had published at least one article on the subject in a top Journal or had led a financial project was prepared and then through contacting via email, the 10 best experts based on their experiences and intention to participate in this study, have been chosen.

The intensities of importance help us to make a pairwise comparison matrix A based on the experts' judgments. Matrix A can be defined as an $m \times m$ matrix, where $\mathrm{m}$ is the number of evaluation criteria considered. In this matrix, the importance (Scales in Table 2 measure the importance) of the $i$ th criterion relative to the $j$ th criterion is represented by entry $a_{i j}$, and the following constraint is satisfied by:

$$
a_{i j} * a_{j i}=1
$$

The maximum value of the eigenvector is calculated in the next step by normalizing the pairwise comparison matrix $A$ through the following equation:

Table 2 Saaty's scale of pairwise comparison

\begin{tabular}{ll}
\hline Intensity of importance & Definition \\
\hline 1 & Equal importance \\
3 & Moderate importance \\
5 & Strong importance \\
7 & Very strong importance \\
9 & Extreme importance \\
\hline
\end{tabular}

Note 2, 4, 6, and 8 intensities of importance may be applied to mention intermediate values

Source Eugenio Leal (2020) 


$$
\bar{a}_{i j}=\frac{a_{i j}}{\sum a_{i j}}
$$

The criteria weight vector of $W$ is calculated by averaging the entries on each row of the normalized pairwise comparison matrix as follows:

$$
W_{j}=\frac{\sum \bar{a}_{i j}}{m}
$$

Finally, the consistency ratio (CR) is checked to verify the reliability of priorities (Rasolinezhad 2009; Tu et al. 2020). Based on the theory of AHP, the consistent pairwise comparison matrix is the one where the largest eigenvalue is equal to its size $\left(\lambda_{\max }=n\right)$. Then, the consistency index $(\mathrm{CI})$ was measured based on the following equation:

$$
\mathrm{CI}=\frac{\lambda_{\max }-n}{n-1}
$$

The consistency ratio (CR), which should be less than 0.01 to show the reliability of results, can be simply calculated by comparing the consistency index (CI) and random consistency index $(\mathrm{RI})$ :

$$
\mathrm{CR}=\frac{\mathrm{CI}}{\mathrm{RI}}
$$

RI (Random consistency index) can be identified based on Table 3 .

\section{Empirical Results}

First, the main objective of our model is to determine the effects of COVID-19 on financial markets. We choose seven criteria and 23 sub-criteria concerning the effects of COVID-19 on the financial markets of capital markets (bond market and stock market), money market, foreign exchange market, and commodity market. The selected sub-criteria were gathered from published papers in the fields of financial markets. Applying the brainstorming technique, we asked the experts to detect the primary critical criteria and factors to remove the least important criteria from our AHP structure (Table 4). Furthermore, four alternatives for decision-making were added to the structure to prioritize them through the experts' judgments. Additionally, following the different impacts of an external shock on developing and

Table 3 Random consistency index

\begin{tabular}{llllllllll}
\hline Matrix size & 1 & 2 & 3 & 4 & 5 & 6 & 7 & 8 & 9 \\
\hline Random consistency & 0.00 & 0.00 & 0.58 & 0.90 & 1.12 & 1.24 & 1.32 & 1.41 & 1.45 \\
\hline
\end{tabular}

Source Tummala and Wan (1994) 
Table 4 The hierarchical structure of our model

\begin{tabular}{|c|c|c|c|}
\hline Objective & Criterion & Factors & Alternatives \\
\hline $\begin{array}{l}\text { Effects of COVID19 on financial } \\
\text { markets }\end{array}$ & B: Social factors & $\begin{array}{l}\text { A1: Eco- } \\
\text { nomic } \\
\text { growth } \\
\text { A2: Interest } \\
\text { rate } \\
\text { A3: Eco- } \\
\text { nomic } \\
\text { stability } \\
\text { A4: Scar- } \\
\text { city } \\
\text { A5: } \\
\text { Demand } \\
\text { reduction } \\
\text { A6: Supply } \\
\text { reduction } \\
\text { B1: Confi- } \\
\text { dence and } \\
\text { expecta- } \\
\text { tions } \\
\text { B2: State's } \\
\text { popularity } \\
\text { B3: Con- } \\
\text { sumption } \\
\text { pattern } \\
\text { B4: Welfare } \\
\text { B5: Sover- } \\
\text { eignty } \\
\text { B6: Band- } \\
\text { wagon } \\
\text { effect }\end{array}$ & $\begin{array}{l}\text { D1: Declaration of a stimulus } \\
\text { package } \\
\text { D2: Central Bank interventions } \\
\text { D3: Support for vulnerable } \\
\text { households } \\
\text { D4: Support of SMEs }\end{array}$ \\
\hline
\end{tabular}

Source Authors' compilation from opinions of experts

developed nations (UNCTAD 2018), the AHP structure, shown in Table 4, is evaluated by the experts for two cases of developing and developed countries.

Two criteria, 13 factors, and five alternatives, associated with the objective, were finalized by the group of experts, as listed in Table 4.

The group of experts performed comparative judgments for the pair of criteria for developing and developed nations. The inputs were analyzed to determine the relative priority of the criteria. The findings, represented in Tables 5 and 6, indicate

Table 5 Compare the relative importance for goal: effects of COVID-19 on financial markets in developed nations

\begin{tabular}{llll}
\hline & A: Economic & B: Social & Weight \\
\hline A: Economic & 2 & 0.667 \\
B: Social & & 0.333
\end{tabular}

Note Inconsistency rate is 0.00

Source Authors' compilation from Expert Choice 10 
Table 6 Compare the relative importance for goal: Effects of COVID-19 on financial markets in developing nations

\begin{tabular}{llll}
\hline & A: Economic & B: Social & Weight \\
\hline A: Economic & & $1 / 3$ & 0.250 \\
B: Social & & 0.750 \\
\hline
\end{tabular}

Note: Inconsistency rate is 0.03

Source: Authors' compilation from Expert Choice 10

that among the two criteria, the experts emphasized more on economic factors (A) in developed nations. At the same time, they thought that social factors (B) are the most important criteria for the transmission channel of the COVID-19 on the financial markets of developing nations.

Then, the group of experts conducted pairwise comparisons to determine the importance of sub-criteria associated with each criterion for the cases of developed and developing nations. Next, the relative weights of sub-criteria related to each criterion are achieved, and the overall ranking of these factors with respect to the goal, which is the effects of COVID-19 on the financial markets of developing and developed nations, is calculated. The findings of the global ranking of the factors are reported in Figs. 3 and 4.

According to Fig. 2, in developed nations, the most critical impact of COVID-19 is A6 (supply reduction), with a final weight of 0.212 . In addition, the experts considered demand reduction (with a weight of 0.169 ) and economic instability (with a weight of 0.117 ) as the second and third major impacts of this pandemic in the financial markets of developed nations. Moreover, based on the final weights, COVID-19

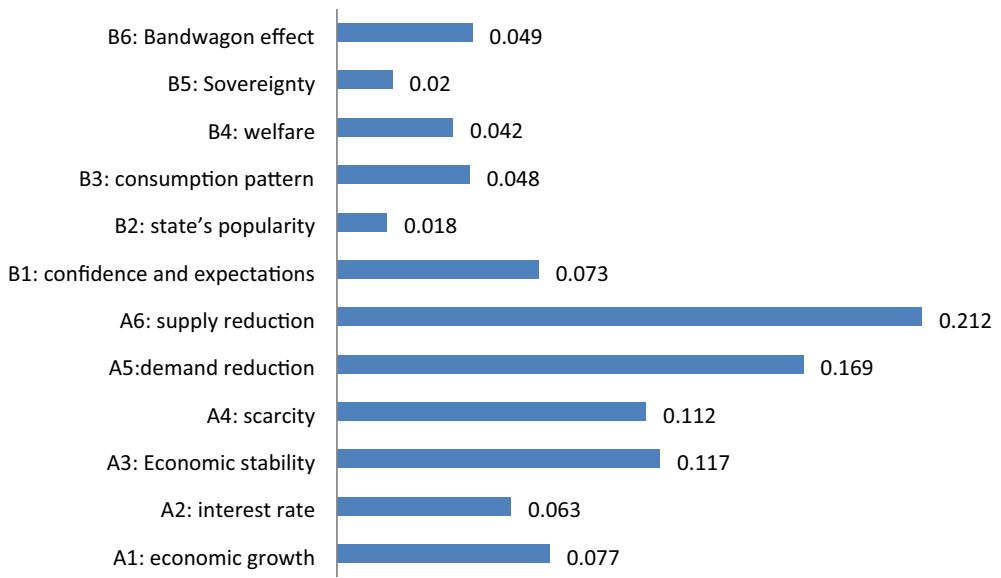

Note: Consistency index is 0.01

Source: Export Choice output

Fig. 2 Overall weights of factors for the goal for the case of developed nations. Note Consistency index is 0.01. Source Export Choice output 


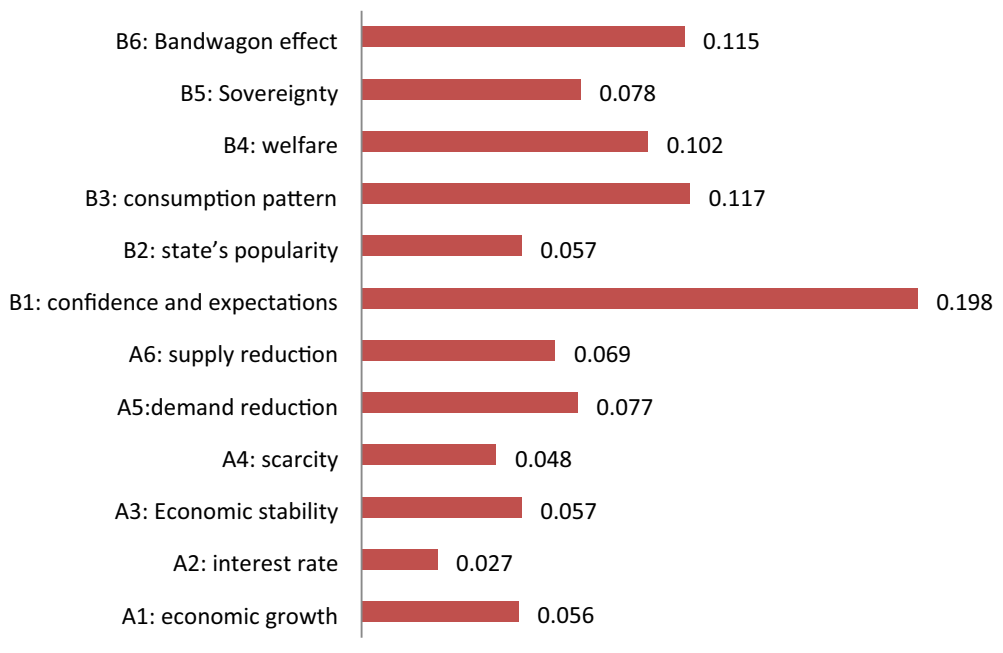

Note: Consistency index is 0.02

Source: Export Choice output

Fig. 3 Overall weights of factors with respect to the goal for the case of developing nations. Note Consistency index is 0.02. Source Export Choice output

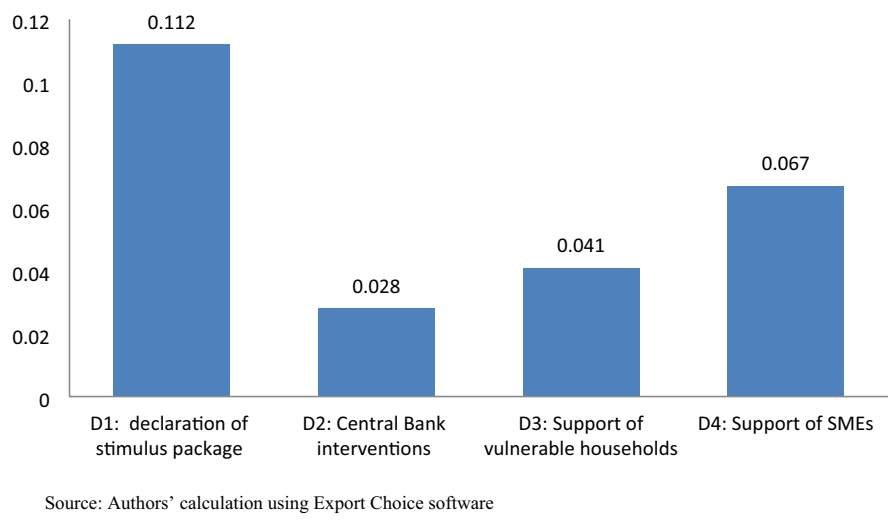

Fig. 4 Weights of alternatives for developed nations. Source Authors' calculation using Export Choice software

has an insignificant effect on the state's popularity, sovereignty, and welfare of societies in developed countries. The main reason would be the market-based economic structure of developed nations, which is more vulnerable to an external shock such as COVID-19. Other reasons may be the higher GDP per capita and income level in these nations, rather than developing ones, covering any financial pressure on people under COVID-19. 
As shown in Fig. 3, confidence and expectations (B1), changes in consumption patterns (B3), and the bandwagon effect (B6) can be considered as the three most significant impacts of COVID-19 on financial markets in developing nations. In addition, interest rate (A2) with a weight of 0.027 and scarcity (A4) with a weight of 0.048 have the least impact on financial markets in developing nations. The main reasons for the more substantial impacts of COVID-19 through social factors in developing nations could be explained by the lower-income level, fear of future economic markets and prices, and the more extensive intervention of governments in the economy in these nations.

The experts made the final decision about the best alternatives, as shown in Figs. 4 and 5. It can be concluded that based on the ranks of the impact of COVID19 on financial markets in developed nations, the best decisions to lower the effects in these nations are the declaration of the stimulus package (D1) (which is in line with the findings of Siddik (2020)) and support of SMEs (D4) with weights of 0.112 and 0.067, respectively. In contrast, for developing countries where COVID-19 has more substantial effects on financial markets through social factors, support of vulnerable households (D2), and declaration of the stimulus package (D1) are the best decisions to combat the adverse effects of COVID-19 on their financial markets.

\section{Conclusions and Policy Recommendations}

It is widely accepted that the coronavirus is not only a global pandemic, but its consequences have also harshly reshaped and affected global markets, economic structures, and mechanisms. This study's main purpose was to evaluate the impacts of the COVID-19 pandemic on the financial markets of developed and developing

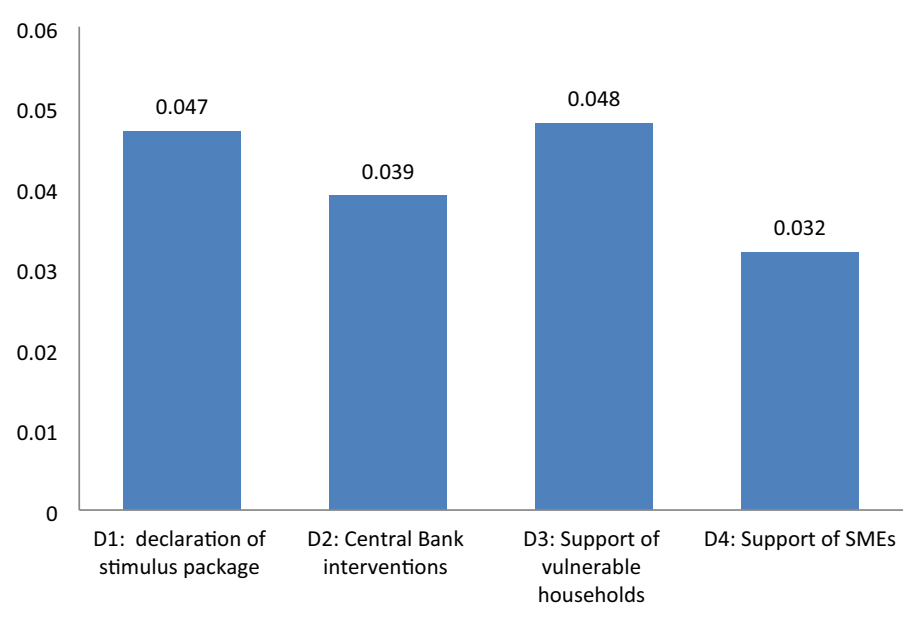

Source: Authors' calculation using Export Choice software

Fig. 5 Weights of alternatives for developing nations. Source Authors' calculation using Export Choice software 
countries using a multi-criteria decision-making model called the analytic hierarchy process (AHP). To carry out the judgments in the AHP model, we asked ten financial and economic experts to conduct pairwise comparisons and then analyzed the combination of their decisions using Expert Choice software. Conducting the research with a structured and logical framework and using the concept of pairwise comparisons through the AHP helped us fill in the literature gap of existing studies that have not addressed the impacts of pandemics through a qualitative and multidimensional methodology.

The main concluding remarks from the results of performing the AHP method are:

(i) The effects of COVID-19 on financial markets differ between developed and developing nations. Hence, there is no similar pattern of COVID-19's impact on financial markets among all countries' levels. This is an important point because of the existence of common thinking about one successful pattern to combat the pandemic's consequences. The localization of successful experiments combating the negative consequences of the coronavirus, such as the model of BeijingSeoul-Tokyo, declared by Wu et al. (2021), attention to traditions, culture and social relations, economic structure, and the quality of interactions with the world should be considered by policymakers in the fight against coronavirus's negative consequences in each country.

(ii) Among the two major criteria, the economic criterion is the most essential transmission channel of COVID-19 to the financial markets of developed nations. In contrast, the social criterion has a more prominent role than the economic one as a transmission channel in the financial markets of developing nations. This conclusion highlights the need to focus on Ulrich Beck's theory of risky society (Cohen 1997) in developing countries, which expresses that external shock (such as COVID-19) can increase the social risks in a country, leading to negative consequences for the national economy.

(iii) COVID-19 affects developed countries' financial markets more through supply reduction, demand reduction, and economic instability. Moreover, this pandemic has the lowest impact on the state's popularity, sovereignty, and welfare of societies in developed nations (this highlight is in line with Topcu and Gulal's (2020) findings). This concluding remark shows that developed nations have smaller challenges for the progress of SDGs (particularly those related to the welfare of societies such as SDG1, SDG2, SDG3, SDG4, and SDG5) than developing nations.

(iv) Regarding developing nations, the experts believed that confidence and expectations, changes in consumption patterns, and the bandwagon effect are the three most significant impacts of COVID-19 on financial markets.

(v) The best decisions to lower the impact of COVID-19 on developed nations' financial markets are the declaration of the stimulus package and support of SMEs, which can boost the progress of SDG9 (industry, innovation, and infrastructure) and SDG8 (decent work and economic growth). In contrast, in the case of developing countries where COVID-19 has more substantial effects on 
financial markets through social factors, support of vulnerable households, and declaration of the stimulus package are the best decisions to combat the negative effects of COVID-19 on their financial markets in such a way that these nations can follow the improvement of SDGs in relation to social life (e.g., SDG1, SDG2, SDG3, SDG4, and SDG5)

As policy implications, it can be noted that countries need rapid and efficient reactions to combat and lower the adverse effects of COVID-19 on different aspects of the economy, particularly the financial markets. Efficient cooperation between the public and private sectors and financial institutions is essential for maximizing all resources to reduce the negative impacts of this pandemic on financial markets. In addition, there should be a plan for short-, medium-, and long-term policies to ensure financial market stability. Supporting vulnerable households and enterprises (i.e., micro and small businesses) should be conducted by governments and central banks. All of these policies can provide a better climate for the progress of SDGs worldwide. The results show that developed nations need policies to support financial firms (SDGs 8-9) under the pandemic consequences, while the pandemic has made more threats to social life in developing nations, which highlights the need for policies related to meeting the SDGs (1-5) in these nations.

Due to governments' fiscal difficulties and the challenge of financial mobilization under the pandemic for meeting SDGs, the authors recommend promoting new financing instruments such as green bonds, impact bonds, and green investment trust funds for fund mobilization from public and private sectors to the projects related to the SDGs.

The authors believe that this study has potential limitations, such as time constraints and limited access to a wide range of experts. Therefore, we recommend future studies to evaluate financial markets separately, compare the results of two methods, AHP and Analytic Network Process (ANP), and invite a more extensive range of participants to respond to the questionnaire. Furthermore, studies related to the financial challenges of green projects (SDG 7 and SDG 13) during the pandemic (e.g. see Sun et al. 2020) are recommended for future studies. Regarding the research methodology, employing econometric techniques to estimate the coefficients of explanatory variables is highly recommended for further research.

Acknowledgements This paper is the revised version of the paper presented on April 5, 2021, at The European Journal of Development Research special issue workshop. The authors are grateful to the guest editor Prof. Rashmi Arora, the workshop participants, and the anonymous reviewers that their comments helped revise the paper and prepare the current version.

Funding The funding was provided by Ministry of Education,Culture, Sports, Science and Technology (Grant No. Grant-in-Aid for Excellent Young Researcher).

\section{Declarations}

Conflict of interest The authors declare that they have no conflict of interest.

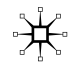




\section{References}

Ackert, L.F. 1994. Uncertainty and volatility in stock prices. Journal of Economics and Business 46 (4): 239-253.

Adedapo Soyemi, K., R. Akingunola, and J. Ogebe. 2017. Effects of oil price shock on stock returns of energy firms in Nigeria. Kasetsart Journal of Social Sciences. https://doi.org/10.1016/j.kjss.2017. 09.004 (in press)

Aharon, D., and S. Siev. 2021. COVID-19, government interventions and emerging capital markets performance. Research in International Business and Finance. https://doi.org/10.1016/j.ribaf.2021. 101492.

Albulescu, C. 2021. COVID-19 and the United States financial markets' volatility. Finance Research Letters. https://doi.org/10.1016/j.frl.2020.101699.

Ankudinov, A., R. Ibragimov, and O. Lebedev. 2017. Sanctions and the Russian stock market. Research in International Business and Finance 40: 150-162.

Atkeson, A. 2020. what will be the economic impact of COVID-19 in the US? Rough estimates of disease scenarios. NBER Working Paper, No. 26867. https://www.nber.org/papers/w26867 [accessed on 13.04.2020].

Atkins, A., M. Niranjan, and E. Gerding. 2018. Financial news predicts stock market volatility better than close price. The Journal f Finance and Data Science 4 (2): 120-137.

Baker, S.R., N. Bloom, S.J. Davis, K. Kost, M.C. Sammon, and T. Viratysin. 2020. The Unprecedented stock market impact of COVID-19. NBER Working Paper Series, 26945. https://www.nber.org/ papers/w26945.pdf

Balcilar, M., M. Bonato, R. Demirer, and R. Gupta. 2016. Geopolitical risks and stock market dynamics of the BRICS. Economic Systems 42 (2): 295-306.

Bancit, A., S. Abidin, and J. Wu. 2016. Are shares more volatile during the global financial crisis? Procedia Social and Behavioral Sciences 224: 221-229.

Barrafrem, K., D. Vastfjall, and G. Tinghog. 2020. Financial well-being, Covid-19 and the financial better than average effect. Journal of Behavioral and Experimental Finance. https://doi.org/10.1016/j.jbef. 2020.100410 .

Bastianin, A., F. Conti, and M. Manera. 2016. The impacts of oil price shocks on stock market volatility: Evidence from the G7 countries. Energy Policy 98: 160-169.

Bloomberg. 2020. Coronavirus could cost the global economy $\$ 2.7$ trillion. Here's how. https://www. bloomberg.com/graphics/2020-coronavirus-pandemic-global-economic-risk/ [data accessed 10.03.2020]/

Castagneto-Gissey, G., and E. Nivorozhkin. 2016. No contagion from Russia toward global equity markets after the 2014 international sanctions. Economic Analysis and Policy 52: 79-98.

Chai, J., N.K. James, E. Liu, and W. Ngai. 2013. Application of decision-making techniques in supplier selection: A systematic review of literature. Expert Systems with Applications. 40: 3872-3885.

Chulia, H., M. Guillen, and J.M. Uribe. 2017. Measuring uncertainty in the stock market. International Review of Economics \& Finance 48: 18-33.

Cohen, M. 1997. Risk society and ecological modernisation alternative visions for post-industrial nations. Futures 29 (2): 105-119.

CSIS. 2020. The Global Economic Impacts of COVID19. https://www.csis.org/analysis/global-economicimpacts-covid-19 [accessed on 13.04.2020].

Donthu, N., and A. Gustafsson. 2020. Effects of COVID-19 on business and research. Journal of Business Research. https://doi.org/10.1016/j.jbusres.2020.06.008.

Dzielinski, M. 2012. Measuring economic uncertainty and its impact on the stock market. Finance Research Letters 9 (3): 167-175.

Elavarasan, R., R. Pugazhendhi, T. Jamal, J. Dyduch, M. Arif, N. Kumar, G.M. Shafiullah, Sh. Chopra, and M. Nadarajah. 2021. Envisioning the UN Sustainable Development Goals (SDGs) through the lens of energy sustainability (SDG 7) in the post-COVID-19 world. Applied Energy. https://doi.org/ 10.1016/j.apenergy.2021.116665.

Elliott, L. 2020. The coronavirus crisis may lead to a new way of economic thinking. The Guardian. https://www.theguardian.com/business/2020/mar/22/the-coronavirus-is-leading-to-a-whole-newway-of-economic-thinking [accessed on 14.04.2020].

Eugenio Leal, J. 2020. AHP-express: A simplified version of the analytical hierarchy process method. MethodsX. https://doi.org/10.1016/j.mex.2019.11.021. 
Fagbemi, F. 2021. COVID-19 and sustainable development goals (SDGs): An appraisal of the emanating effects in Nigeria. Research in Globalization. https://doi.org/10.1016/j.resglo.2021.100047.

Fenner, R., and T. Cernev. 2021. The implications of the Covid-19 pandemic for delivering the Sustainable Development Goals. Futures. https://doi.org/10.1016/j.futures.2021.102726.

Ferguson, N. 2008. Earning from History? Financial markets and the approach of world wars. Brookings Papers on Economic Activity 2008: 431-477.

France 24 News Agency. 2020. Says coronavirus worst global crisis since World War II. https://www. france24.com/en/20200401-un-chief-says-coronavirus-worst-global-crisis-since-world-war-ii [accessed on 01.04.2020].

Gompf, K., M. Traverso, and J. Hetterich. 2021. Using analytical hierarchy process (AHP) to introduce weights to social life cycle assessment of mobility services. Sustainability 13: 1258. https:// doi.org/10.3390/su13031258.

Gormsen, N.J., and R.S. Koijen. 2020. Coronavirus: Impact on stock prices and growth expectations. Becker Friedman Institute for Economics Working Paper, No. 2020-22. https://papers.ssrn.com/ sol3/papers.cfm?abstract_id=3555917 [accessed on 14,.04.2020].

Hudson, R., and A. Urquhart. 2015. War and stock markets: The effect of World War Two on the British stock market. International Review of Financial Analysis 40: 166-177.

Jin, X., and X. An. 2016. Global financial crisis and emerging stock market contagion: A volatility impulse response function approach. Research in International Business and Finance 36: $179-195$.

Le, T., and Y. Chang. 2015. Effects of oil price shocks on the stock market performance: Do nature of shocks and economies matter? Energy Economics 51: 261-274.

Lewis, K.K., and E.X. Liu. 2017. Disaster risk and asset returns: An international perspective. Journal of International Economics 108 (1): S42-S58.

Li, L., L. Yin, and Y. Zhou. 2016. Exogenous shocks and the spillover effects between uncertainty and oil price. Energy Economics 54: 224-234.

Li, S., and Y. Yan. 2021. DATA-driven shock impact of COVID-19 on the market financial system. Information Processing \& Management. https://doi.org/10.1016/j.ipm.2021.102768.

Li, W., F. Chien, H.W. Kamran, T. Al-Deehani, M. Sadiq, V.C. Nguyen, and F. Taghizadeh-Hesary. 2021. The nexus between COVID-19 fear and stock market volatility. Economic ResearchEkonomska Istraživanja. https://doi.org/10.1080/1331677X.2021.1914125.

Liu, Y., L. Han, and L. Yin. 2019. News implied volatility and long-term foreign exchange market volatility. International Review of Financial Analysis 61: 126-142.

Louhichi, W., Z. Ftiti, and H.B. Ameur. 2021. Measuring the global economic impact of the coronavirus outbreak: Evidence from the main cluster countries. Technological Forecasting and Social Change. https://doi.org/10.1016/j.techfore.2021.120732.

Lyocsa, S., E. Baumohl, T. Vyrost, and P. Molnar. 2020. Fear of the coronavirus and the stock markets. Finance Research Letters. https://doi.org/10.1016/j.frl.2020.101735.

Martin, F.M. 2020. Economic Realities and consequences of the COVID-19 pandemic-Part I: financial markets and monetary policy. Economic research, Federal Reserve Bank of St. Louis. https:// research.stlouisfed.org/publications/economic-synopses/2020/03/30/economic-realities-andconsequences-of-the-covid-19-pandemicpart-i-financial-markets-and-monetary-policy [ accessed on 14.04.2020].

Mckibbin, W., and R. Fernando. 2020. The global macroeconomic impacts of COVID-19: Seven scenarios. CAMA Working Paper Series, 19/2020. https://cama.crawford.anu.edu.au/publication/ cama-working-paper-series/16221/global-macroeconomic-impacts-covid-19-seven-scenarios.

Mulugeta, T., E. Tadesse, T. Shegute, and T. Desta. 2021. COVID-19: socio-economic impacts and challenges in the working group. Heliyon. https://doi.org/10.1016/j.heliyon.2021.e07307.

OECD. 2020. Coronavirus: The world economy at risk. https://www.oecd.org/berlin/publikationen/ Interim-Economic-Assessment-2-March-2020.pdf [accessed on 14.04.2020].

Ozkan, O. 2021. Impact of COVID-19 on stock market efficiency: Evidence from developed countries. Research in International Business and Finance. https://doi.org/10.1016/j.ribaf.2021.101445.

Padhan, R., and K.P. Prabheesh. 2021. The economics of COVID-19 pandemic: A survey. Economic Analysis and Policy 70: 220-237.

Pak, A., O. Adegboye, A. Adekunle, K. Rahman, E. McBryde, and D. Eisen. 2021. Economic consequences of the COVID-19 outbreak: The need for epidemic preparedness. Frontiers in Public Health 8: 241. https://doi.org/10.3389/fpubh.2020.00241. 
Pan, S., and S. Zhang. 2020. From fighting COVID-19 pandemic to tackling sustainable development goals: An opportunity for responsible information systems research. International Journal of Information Management. https://doi.org/10.1016/j.ijinfomgt.2020.102196.

Pitterle, I., F. Haufler, and P. Hong. 2015. Assessing emerging markets' vulnerability to financial crisis. Journal of Policy Modeling 37 (2): 484-500.

Rasolinezhad, E. 2009. Evaluating electronic banking systems in developing nations through Analytic Hierarchy Process model: A case study. International Journal of Electronic Finance 3 (4): 325-338.

Rehse, D., R. Riordan, N. Rottke, and J. Zietz. 2019. The effects of uncertainty on market liquidity: Evidence from Hurricane Sandy. Journal of Financial Economics 134 (2): 318-332.

Rigobon, R., and B. Sack. 2005. The effects of war risk on US financial markets. Journal of Banking \& Finance 29 (7): 1769-1789.

Romero Cortes, K., and Ph. Straan. 2017. Tracing out capital flows: How financially integrated banks respond to natural disasters. Journal of Financial Economics 125 (1): 182-199.

Saaty, T., and L. Vargas. 1980. Hierarchical analysis of behavior in competition: Prediction in chess. Behavioral Science 25 (3): 180-191.

Samadi, A., S. Owjimehr, and Z. Halafi. 2021. The cross-impact between financial markets, Covid-19 pandemic, and economic sanctions: The case of Iran. Journal of Policy Modeling 43 (1): 34-55.

Schneider, G., and V.E. Troeger. 2006. War and the World Economy: Stock Market Reactions to International Conflicts. The Journal of Conflict Resolution 50 (5): 623-645.

Segal, G., I. Shaliastovic, and A. Yaron. 2015. Good and bad uncertainty: Macroeconomic and financial market implications. Journal of Financial Economics 117 (2): 369-397.

Shiller, R.J. 2020. Predictions for the Coronavirus Stock Market. The New York Times. https://www. nytimes.com/2020/04/02/business/stock-market-predictions-coronavirus-shiller.html [accessed on 13.04.2020].

Siddik, M. 2020. Economic stimulus for COVID-19 pandemic and its determinants: evidence from crosscountry analysis. Heliyon. https://doi.org/10.1016/j.heliyon.2020.e05634.

So, M., A. Chu, and T. Chan. 2021. Impacts of the COVID19 pandemic on financial market connectedness. Finance Research Letters. https://doi.org/10.1016/j.frl.2020.101864.

Sun, Y., L. Chen, H. Sun, and F. Taghizadeh-Hesary. 2020. Low-carbon financial risk factor correlation in the belt and road PPP project. Finance Research Letters. https://doi.org/10.1016/j.frl.2020.101491.

Taghizadeh-Hesary, F., N. Yoshino, and H. Phoumin. 2021. Analyzing the characteristics of green bond markets to facilitate green finance in the post-COVID-19 World. Sustainability 13 (10): 5719. https://doi.org/10.3390/su13105719.

Topcu, M., and O. Gulal. 2020. The impact of COVID-19 on emergning stock markets. Finance Research Letters. https://doi.org/10.1016/j.frl.2020.101691.

Tu, Ch., E. Rasoulinezhad, and T. Sarker. 2020. Investigating solutions for the development of a green bond market: Evidence from analytic hierarchy process. Finance Research Letters (in press) https:// doi.org/10.1016/j.frl.2020.101457

Tummala, V., and Y. Wan. 1994. On the mean random inconsistency index of analytic hierarchy process (AHP). Computers \& Industrial Engineering 27 (1-4): 401-404.

Uddin, M., A. Chowdhury, K. Anderson, and K. Chaudhuri. 2021. The effect of COVID-19 pandemic on global stock market volatility: Can economic strength help to manage the uncertainty? Journal of Business Research. 128: 31-44.

UNCTAD. 2018. Building resilience to multiple shocks affecting people and sustainable development. https://unctad.org/meetings/en/SessionalDocuments/tdb65_1_d5_en.pdf [ accessed on 15.04.2020].

UNCTAD. 2020. The Covid-19 shock to developing countries. UNCTAD Report, INF/2020/2. https:// unctad.org/en/PublicationsLibrary/gds_tdr2019_covid2_en.pdf [accessed on 13.04.2020].

Vera-Valdes, J. 2021. The persistence of financial volatility after COVID-19. Finance Research Letters (in press) https://doi.org/10.1016/j.frl.2021.102056.

Vieira, K., A. Potrich, A. Bressan, and L. Klein. 2021. Loss of financial well-being in the COVID-19 pandemic: Does job stability make a difference? Journal of Behavioral and Experimental Finance. https://doi.org/10.1016/j.jbef.2021.100554.

Vittuari, M., M. Masotti, E. Lori, L. Falasconi, T. Toschi, and A. Segre. 2021. Does the COVID-19 external shock matter on household food waste? The impact of social distancing measures during the lockdown. Resources, Conservation and Recycling. https://doi.org/10.1016/j.resconrec.2021. 105815 .

Vorbrink, J. 2014. Financial markets with volatility uncertainty. Journal of Mathematical Economics 53: 64-78. 
Wang, H., and A.L. Boatwright. 2019. Political uncertainty and financial market reactions: A new test. International Economics 160: 14-30.

Wang, Q., and R. Huang. 2021. The impact of COVID-19 pandemic on sustainable development goalsA survey. Environmental Research. https://doi.org/10.1016/j.envres.2021.111637.

Wu, F., Q. Hu, C. Zhu, H. Wang, Q. Yu, and H. Sun. 2021. New structural economic analysis of antiCOVID-19 pandemic model of BEST region. International Journal of Environmental Research and Public Health 18 (15): 7822. https://doi.org/10.3390/ijerph18157822.

Wunder, S., D. Kaimowitz, S. Jensen, and S. Feder. 2021. Coronavirus, macroeconomy, and forests: What likely impacts? Forest Policy and Economics. https://doi.org/10.1016/j.forpol.2021.102536.

Yildirim-Karaman, S. 2018. Uncertainty in financial markets and business cycles. Economic Modelling 68: 329-339.

Yoshino, N., F. Taghizadeh-Hesary, and M. Otsuka. 2021. Covid-19 and optimal portfolio selection for investment in sustainable development goals. Finance Research Letters. https://doi.org/10.1016/j.frl. 2020.101695.

Yousfi, M., Y. Zaied, N. Cheikh, B. Lahouel, and H. Bouzgarrou. 2021. Effects of the COVID-19 pandemic on the US stock market and uncertainty: A comparative assessment between the first and second waves. Technological Forecasting and Social Change. https://doi.org/10.1016/j.techfore.2021. 120710.

Zaremba, A., D. Aharon, E. Demir, R. Kizys, and D. Zawadka. 2021. COVID-19, government policy responses, and stock market liquidity around the world: A note. Research in International Business and Finance. https://doi.org/10.1016/j.ribaf.2020.101359.

Publisher's Note Springer Nature remains neutral with regard to jurisdictional claims in published maps and institutional affiliations. 